TiC 基サーメットと WC-Co 超硬合金との接着強度

寺田修放，佐々木 章汸，鈴木 寿ふ2

か1 富士ダイス儌技術部，勇146 大田区下丸子2-17-10.

的 千葉工業大学工学部, $\overline{\mathbf{T}} 275$ 習志野市津田沼2-17-1.

\title{
Adhering Strength between Titanium Carbide Based Cermet and WC-Co Cemented Carbide
}

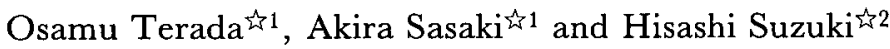 \\ t1 Technical Development Div., Fuji Die Co., 2-17-10 Shimomaruko Ohta-ku, Tokyo 146. \\ से2 Faculty of Engineering, Chiba Institute of Technology, 2-17-1 Tsudanuma, Narashino 275.
}

Received March 31, 1992

The room temperature adhering strength of combined specimen prepared by adhesion between TiC-19mass\%Mo $2 \mathrm{C}-24 \mathrm{mass} \% \mathrm{Ni}$ cermet and $\mathrm{WC}-(10,15)$ mass\%Co cemented carbide was mainly studied by transverse-rupture tests. It was found that the main crack generally passed within the cermet region very neighbouring the interfacial layer formed between two sorts of alloys. It was also found that the strength increased with lowering the adhering temperatures. The reason for the above phenomena is discussed.

\section{1 精夆}

著者らは，サーメットと WC-Co䂏硬合金との複合工具 彆造において重要となる，両合金の接着に関する基礎研 究を行ない，多くの知見を得ることが出来た ${ }^{1)}$. 中でも， 接着時にサーメット側から一般に超硬合金側にN 液相の 流動が生し，就験片に寸法 (体皘) 変化, 組織变化, 硬 さ変化などを㟟起する現象は, 極めて興味ある知見と思 われた，ここでは既報”の結果をふまえ，両合金の接 兼強度について険討を加えることにした。

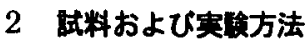

試料としては，高炭素のT iC-19mass\%Mo 2 C-24mass $\% \mathrm{Ni}$ サーメットと高炭素のWC- $(10,15)$ mass $\%$ Co超硬合金を用 いた*1)。ここで結合相の体積率はサーメットは約16.4，

*1) 既報" ではTiC-19mass\% $\% 0_{2} \mathrm{C}-24$ mass $\%$ Ni とWC-10mass\%
超硬合金は 16.4 と23.6vol\%となる。両合金とも，常 法に従って真空焼結によって鲖製（寸法はほほ $6 \times 8.5$ $\left.\times 12 \mathrm{~mm}^{3}\right)$ し, その後HIP処理した. HIP処理後のサーメッ 卜及び超硬合金の抗折力はそれぞれ約 $2.0,3.4 \sim 3.6 \mathrm{GPa}$ であった。必要により窒素（N)入りのTiC-19mass\% No $_{2} \mathrm{C}$ 14mass\%TiN-24mass\%Niサーメットも試料として用いた。 サーメットと超硬合金との接着方法は，既報" と同様， 嬈結体の端面を研削，研摩後，サーメットと超硬合金を

Co(結合相の体積事はいずれの合金も16.4\%）との接着につ いて検討したが，超硬合金のCo量については 10 より 15 mass\%co とした方が，結果的に接着強度が安定し，他方工 具龬へのろう付性も優れるので，ここでは $15 \mathrm{mass} \%$ Co 合 金も試料として用いた. 15 mass\%Coの埸合も接着時にサー メット睢から超硬合金側にNi液相が流動するが，流動量は 10 mass\%Coの場合よりも浅少した(後述). 
研摩面で接触させ， $1300^{\circ} \mathrm{C} て ゙ \mathrm{~h}$ の真空予備接着後，1340 $1400^{\circ} \mathrm{C}$ 各温度で $1 \mathrm{~h} の$ 最終接着を行なった。接着試料の 寸法はほぼ $6 \times 8.5 \times 24 \mathrm{~mm}^{3}$ であるが, これを研削仕上げに より $5 \times 8 \times 24 \mathrm{~mm}^{3}$ の寸法とした後, 抗折試験に供した. こ の時必要に応じて, 張力面を研摩仕上げした抗折試片も作 った. 抗折試験は接着界面層中心をスパン中心に一致する ようにして行い，抗折破壊後は，張力面における主亀裂の 伝播経路と界面組織との関係, 破面組織, 破壞の起源なと を詳しく調べ，抗折力(接着強度)に及ぼす支配因子を調人゙ た.

\section{3 实䋡結果および考察}

Photo.1はサーメットと $10 \% \mathrm{C}_{0}$ 合金との接着試片 $\left(1360^{\circ} \mathrm{C}\right.$ $\mathrm{x} \mathrm{lh}$ )を抗折破壊し，破片を突き合わせた時の張力面のSEM 組織である. この時張力面は十分に研摩しておいた。 Phot 0.1 によると, 主龟裂は接着界面首に接するサーメッ 卜内部を通過することが分かる．接着温度が変化した場合

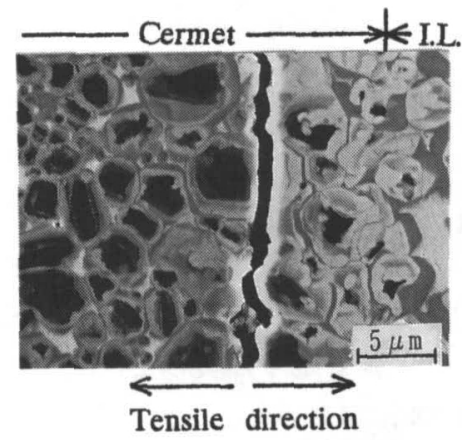

Photo.1 SEM micrograph of a main crack appearing on tension side surface of specimen, when $\mathrm{TiC}-19$ mass $\% \mathrm{Mo}_{2} \mathrm{C}-24$ mass\% $\mathrm{Ni} /$ WC-15mass\%Co combined specimen was transverse-ruptured. It is shown that the main crack passes within cermet very neighbourig interfacial layer (I.L.) formed between cermet and cemented carbide.

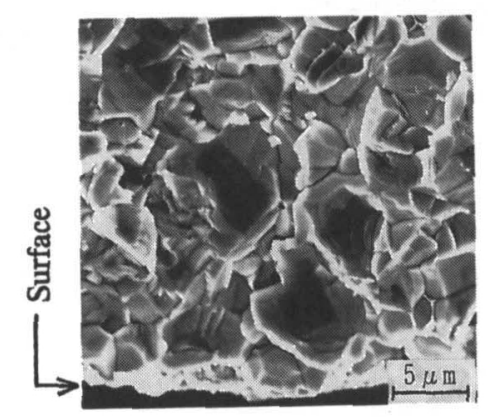

Photo.2 Fracture surface, showing that the fracture source of combined specimen corresponded to a coarse $\beta$ phase. Refer to photo.1.
や超硬合金のCo量を多量とした場合についても調べたが， 上記の現象は同様となった，そこで破面組織を調べ，結果 例をPhoto.2に揭げた。 これより亀裂は試片表面近くに存 在する粗粒 $\beta$ 相(周辺組織を有するTiC粒) から生じること が明らかであり，この現象も接着温度や超硬合金のCo量に よって変らなかった.

次に試片の接着強度を調べた. Photo.1の結果によると, 主俥裂がサーメット内部を通過するので, 抗折力の值はサ ーメットと超硬合金との接着強度でないことは明らかであ るが, 便宜的に以下接着強度とい5。 Fig.1はサーメット と 10 および15\%CO合金との接着强度と接着温度との関係を 示すこれより接着温度が低い程，C0量によらず高強度と なることが分かる. 以下この理由を考える. (1)高温接着を 行ら程サーメット側の Niが超硬合金側に流入し易くなり, サーメット中の $\mathrm{Ni}$ 量が娍少する”が，本研究の $10 \% \mathrm{C} 0$ の場 合は勿論 $15 \%$ Cの場合も同様となることが確かめられた。 しかし，Ni 液相の流動量は10よりも15\%C0の方が少なく

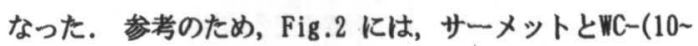

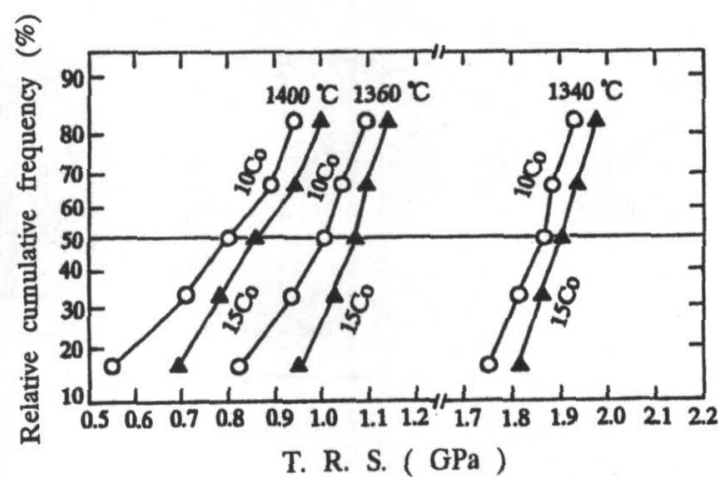

Fig.1 Transverse-rupture strength (adhering strength ) of TiC-19Mo2 $\mathrm{C}-24 \mathrm{Ni} / \mathrm{WC}-(10,15)$ Co specimen as a function of adhering temperatures.

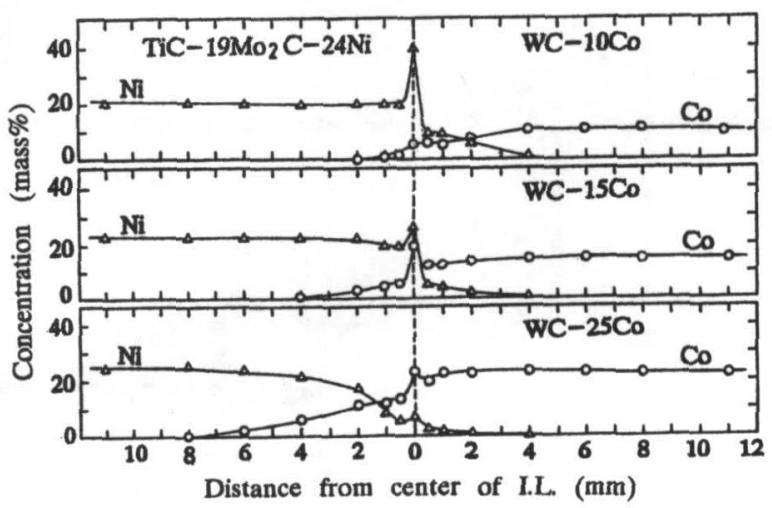

Fig.2 The nickel and cobalt concentration in cermet / WC-Co combined specimen prepared at $1360{ }^{\circ} \mathrm{C}$ for $1 \mathrm{~h}$. 
25)％Ｃ０合金との接着において，Co量が多くなる程Ni流動量 が少なくなることを示した. (2)超硬合金偵からサーメット 側に畹流入し，高温接着を行う程 $\beta$ 相が粗大化する゙が， 15\%C0合金の場合も同様となることが確かめられた。

即ちサーメットはもともと超硬合金よりも低強度である (既述)が, 上記(1)によるとNi量が堿少するのでさらに低強 度となることと，(2)よると粗粒 $\beta$ 相が応力集中源となり 易くなるため, 主量裂は界面層に接するサーメット中を通 過し, 高温接着を行う程, 接着強度が低下したと考えられ た. Fig.1 において, 接着温度が同一ならば, 10よりも $15 \% C_{0}$ 合金の方が高強度となったが，これは高 $\mathrm{C}_{0}$ 合金程， Niの流出量が抑えられるからとして説明出来ると思う。

Phot 0.3 は接着試料 $\left(15 \% \mathrm{C} 0\right.$ 合金, $\left.1340^{\circ} \mathrm{C} \times 1 \mathrm{~h}\right)$ の界面層近 傍に付したHv (490N) 圧痕を示す. Hv圧痕隅部に龟裂を生じ るが，サーメット側では，角裂長は試片の長手方向におい て直角方向よりも長くなっている, 即ちサーメット側では 試片直角方向に残留張力が存在していることが分かる。 そ して, これはサーメットの方が熱膨張係数が大きいためと

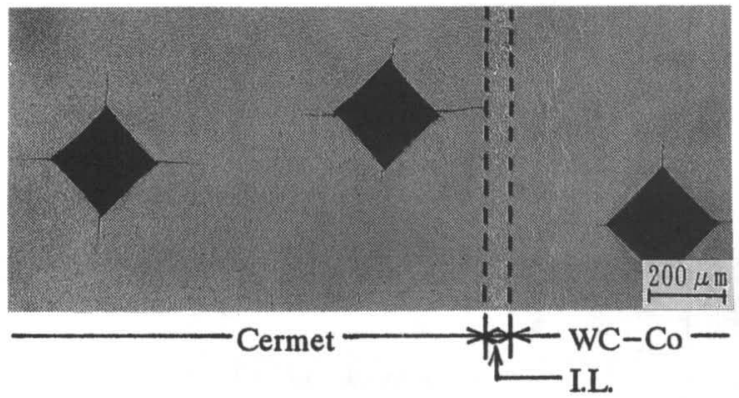

Photo.3 The Vickers hardness indentations ( load, 490N), made on the cermet / WC-15Co specimen surface.

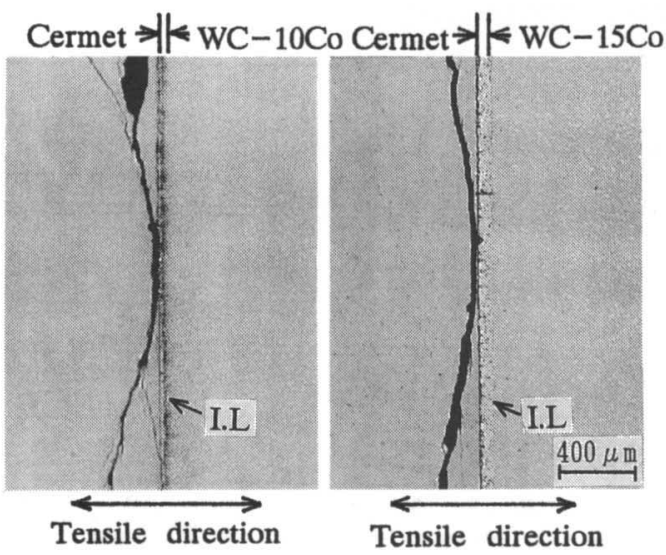

Photo.4 A bend of a main crack within cermet region, with low magnification. Refer to photo.1.
してよい*11)。の点,本研究の抗折試験では破壊時の張力 方向が試片の長手方向となっているので, 上記の残留張力 は，抗折力に影響しないと思われた. Photo.4にはPhoto.1 に対応するマクロ組織を示した。.これより主刍裂が超硬 合金側に対して 凸に湾曲していることが明らかであるが， これは上記の残留張力の影筫と見做された。 すなわち，残 留張力は主刍裂の伝播経路に影響を与えるとしても, 強度 には影櫄しないと思われた. 付記すると Photo.3に示した 試料について, 600 800 $\mathrm{C}$ で $20 \mathrm{hr}$ までの低温焼鈍後に刍裂 長の異方性や抗折力を測定したところ，それらはとくに変 化しないと見做された.

以下 $\mathrm{N}$ 入りサーメットと林-C0合金との接着強度の結果 を要約する．まず抗折破壊時の主刍裂の伝播経路，破壤の 起源は, N無添加サーメットの場合と同様であった. 接着 強度に及ぼす超硬合金のC0量の影警もN無添加サーメット の場合と同様となった。 しかし，接着温度の影蠁はN無添 加の場合よりも小さくなった. これは恐らくN添加サ ーメットは微粒炭化物組織のため $\mathrm{Ni}$ の流出量が減少する ${ }^{11}$ ことと, 界面層近くのサーメット中の $\beta$ 相粒度の成長が抑 えられる*2)ことなどに起因すると思われた.

\section{4 結䛲}

主としてTiC-19mass\% $\mathrm{Mo}_{2} \mathrm{C}-24 \mathrm{mass} \% \mathrm{Ni}$ サーメットとWC (10 15) mass\%Co合金とを1340 1400 Cで接着させ, 抗折力 試験による接着強度や, 組織稓察による主刍裂の伝播経路 なとを詳しく調へ，以下の諸結果を得た.

1)抗折破壊時に張力面に生じる主刍裂は，両合金の接着界 面に接するサーメットの内部領域を通過し，その経路は 超硬合金側に対し凸状に湾曲する. ここで後者の現象は， サーメット側に生じる残留張力に起因すると思われた. なお、抗折破壊は試片表面近傍に存在する粗粒 $\beta$ 相を起 源として生した。接着温度が高くなる程, 接着強度が低 下する現象が見いだされたが，これは高温接着を行う程， サーメット中の Ni 量が诚少し, サーメットの強度が接着 前よりも低下寸るためと考えられた. ここで接着強度の 語は，主亀裂の経路を考慮すると正しくないが，便宜的

*1) TiC-19 massw\%MO $_{2} \mathrm{C}-24$ mass\%a i とWC- $(10,15)$ mass\%Coの 熱澵張係数は便宜的に文献值 ${ }^{2}{ }^{3)}$ を用いて，混合則 により計算すると $8.26,\left(5.90\right.$ 6.46) $\times 10^{-6} / \mathrm{K}$ とな る.

*2） N入りサーメットの場合は, 超硬合金側からサーメッ 卜側にWが拡散しても，Nの存在でWはMo と同様に周辺 組織中への固溶が抑えられ， $\beta$ 相はほとんと粒成長 しない゙. 
に使用した．接着強度に及ぼすWC-Co合金のCo量の影策 は囬Co程，高強度を示す㮌向にあった。

2)望素添加サーメットと $\quad$ WC-Co合金とを組み合わせた場合 の諸現象は上記とほぼ同様となった。但し，接着温度の 接着強度に及ぼす影烈は，窒掌無添加合金の場合よりも 小さくなった.

文献

1)寺田，佐々木，鈴木：秎体およひ粉末治金， 39 (1992)，
投稿中.

2)L.E.Toth : Transition Metal Carbides and Nitrides, Academic Press, N.Y., (1971), 7.

3)日本金属学会䋧：金属データブック，丸善，(1974)， 13.

4)土屋，寺田，佐々木，鈴木：紛体および粉末冶金， 37 $(1990), 562$. 